\title{
Evolution of Rural Homestead Rights System in China
}

\author{
Lingyan $\mathrm{Lv}^{1}$, Xiangjiao $\mathrm{Li}^{2}$ and Jiajia $\mathrm{Li}^{3}$ * \\ ${ }^{1}$ School of Public Administration, China University of Geosciences, Wuhan 430074, China; \\ ${ }^{2}$ School of Public Administration, China University of Geosciences, Wuhan 430074, China.
}

Keywords: Rural land; The right to use homestead; Right system; Reform

Abstract. Since the founding of New China, the rural homestead right system has undergone many changes, from private ownership during the land reform period to collective ownership after the completion of the three major reforms. The current system of rural homestead right of use originated in the period of three major reforms. After the people's commune movement, it has made great progress. With the continuous development and improvement of society, it has laid a foundation for the establishment of the system of rural homestead right of use in China. Since the reform and opening up, with the development of contemporary rural economic model and the change of farmers' life model, the current homestead right system can no longer meet the needs of social development and farmers' life. The reform of homestead right to use is the institutional response to the development and change of rural production relations.

\section{Evolution of Homestead Right System}

\subsection{Homestead privatization period}

After the founding of the People's Republic of China, China has established a land system privately owned by farmers, who have the ownership of homestead. In the period of primary cooperatives, the 1950 "Land Reform Law" clearly stated: "Abolish the land ownership of feudal exploitation by the landlord class and implement the land ownership of farmers[1]". Farmers can buy, sell, rent and inherit homestead, establishing farmers' ownership of land and houses, and farmers enjoy almost complete ownership of cultivated land and homestead. At the stage when land is privately owned by farmers, the state gives farmers full land rights, and farmers can dispose of their land according to law after obtaining land ownership certificates. The 1954 Constitution of China also clearly stipulates the protection of farmers' land ownership. In the period of senior cooperatives, the second paragraph of Article 16 of the Model Regulations for Senior Agricultural Production Cooperatives, adopted on June 30, 1956, stipulates that agricultural houses and land owned by members before that time need not be classified as senior cooperatives. It can be seen from this that even in the period of advanced cooperatives, the regulations of the previous period of primary cooperatives has been continued. There has not been much substantial change in farmers' land rights, and farmers still enjoy the ownership of homestead.

In this historical period, just after the founding of New China, due to the influence of the social and historical conditions at that time, all systems were not perfect and social development was also in the exploratory stage. The homestead at that time was owned by the farmers themselves. In order to truly realize the status of the people as masters of their own affairs and to maximize the interests of the people, homestead is allocated on an individual basis and also obtained free of charge, guaranteeing farmers' basic right to subsistence. In addition, it also stipulates that the ownership of the homestead and the ownership of the farm house are owned by farmers, allowing them to rent, buy, sell and mortgage the homestead. This shows that the homestead system at this stage has played a dual role of security and property.

\subsection{Homestead collectivization period}

With the completion of the three major reforms in 1956, the land changed from private to public. After entering the people's communalization movement, the ownership of rural homestead changed from peasant ownership to collective ownership. Under the historical conditions at that time, in order to improve production efficiency, during this period, the ownership of homestead was owned by the rural collective economic organizations, while the farmers lost ownership and only retained the right to use it. 
In this case, the right to dispose of farmers under the previous Land Reform Law was restricted or prohibited. For example, article 2, paragraph 1, of the 1963 notice of the central Committee of the communist party of China on making some supplementary provisions on homestead issues for members stipulates that no matter whether houses are built or not, rural homestead may be punished. Due to the separation of land ownership from housing rights, the second paragraph of Article 2 of the Notice also stipulates: "The attachments on the homestead will always be owned by members, who have the right to buy, sell or lease houses. After the house is sold, the right to use the homestead will be transferred to the new owner, but the ownership of the homestead will still be owned by the production team [2]." This provision is somewhat similar to China's current homestead system.

During this period, the rural homestead was distributed by households. The right to use homestead has been separated from the ownership, and there is duality in the distribution of the subject of power, and the boundaries of this right are not very clear. Farmers only enjoy the right to use and the ownership of agricultural houses, but this right has also been greatly restricted, such as no circulation, mortgage, transfer and so on, but there is no restriction on the ownership of houses above the homestead. This shows that the homestead system at this stage pays too much attention to the security of homestead but ignores its property.

Until the reform and opening up, the state has strictly restricted the transfer of the right to use homestead. For example, Article 3 of the State Council's Emergency Notice on Preventing Rural Housing from Seizing Cultivated Land in 1981 stipulates: "For homestead assigned to members, members only have the right to use it, but are not allowed to rent, buy, sell or transfer without authorization, nor to build houses, etc.[3]." The second paragraph of Article 15 of the Regulations on the Administration of Rural Housing Land in 1982 stipulates:" Anyone who sells or rents a house shall not apply for homestead again [4]." This provision has also included houses above the homestead in the ban on circulation, which is stricter than the previous provision. Article 38 of the 1986 Land Administration Law stipulates that the application for homestead after selling or renting houses shall not be approved[5]. This provision continues and reinforces the previous provision. This shows that in the period of collectivization of homestead, farmers only enjoyed the right to use homestead, but they were not allowed to dispose of it at will due to historical conditions such as rural social economy at that time. It can be seen from this that the state is based on the consideration of farmers' basic survival interests, the land as the foundation of living, needs to be given special protection. Therefore, the homestead system in each period has the historical color of that time, and its function and purpose are different. However, with the gradual disintegration of the dual structure of urban and rural areas, the function of homestead has gradually changed, and the current homestead system has gradually failed to meet the needs of the current rural social development.

\section{The Specific Content of Homestead Right System}

At present, the provisions on homestead rights are mainly scattered in the Constitution, Property Law, Land Administration Law and Guarantee Law, as stipulated in Article 10 of the Constitution: "Urban land belongs to the state. Land in rural and suburban areas belongs to collectives, except as stipulated by law to be owned by the state. Homestead and private plots and private hills also belong to collective ownership [6]";Article 152 of the Property Law stipulates: " Homestead users shall have the right to occupy and use collectively owned land according to law, and shall have the right to use the land to build houses and ancillary facilities according to law" and Article 154 stipulates: " Homestead use rights shall disappear if they are lost due to natural disasters, and villagers who have lost homestead shall redistribute homestead [7]"; Article 62 of the " Land Management Law" stipulates: " Rural villagers can only own one homestead, and the area of the homestead shall not exceed the standards set by provinces, autonomous regions and municipalities directly under the Central Government "; Article 37 of the Guarantee Law stipulates: " The following properties shall not be mortgaged; (1) Land use rights owned by collectives such as cultivated land, homestead, private plots and private hills, except as provided for in Article 34 (5) and Article 36 (3) of this Law." From the above list, it can be seen that the Constitution 
determines that the homestead belongs to the collective. The "Property Law" and "Guarantee Law" stipulate the rights enjoyed by farmers. The Law on Land Administration sets forth requirements for the exercise and acquisition of the right to use homestead. Although there are some regulations on homestead rights in our country at present, there is no law to specifically adjust the homestead system in our country, and the relevant legal system still needs to be improved.

China's current homestead use right system began in the 1980s. Due to economic development, the asset function of homestead has gradually become prominent, and some regions have also tried to transfer it. In 2004, there were some changes in the policy, and the breakthrough in the transfer of the right to use the homestead came into people's view. In the relevant policies promulgated by the State Council in 2004, the way and rules for non-agricultural construction land entering the market were stipulated. This has laid a policy foundation for exploring the transfer system of homestead use right. On the acquisition of homestead and other issues, the property law of 2007 did not make relevant provisions, but adopted an evasive attitude, believing that homestead should fall within the scope of adjustment of relevant laws and regulations such as land management law. Although the property law does not directly specify the relevant issues, it throws the issue to the Land Management Law, thus reserving a certain legal space for the transfer of the right to use the homestead. However, the law has not been amended since 2007. Article 62 of the law still imposes restrictions on the transfer of homestead. Farmers who lose their homestead because of selling agricultural houses cannot apply for it again. In addition, article 63 emphasizes that the right to use rural land can only be used for agriculture, not for other purposes. From this, it can be seen that China's laws still prohibit the transfer of the right to use homestead. In 2008, the decision issued by the Third Plenary Session of the Seventeenth Central Committee clearly stated that the management of rural homestead should be strengthened and its usufructuary right attribute should be fully played. This decision proposed for the first time the protection of farmers' usufructuary right of homestead, reflecting the development possibility of its property function.

China's current homestead use right system explicitly prohibits the transfer of homestead use right. However, with the deepening of the process of urban-rural integration, farmers' demand for funds is increasing and farmers' financing channels are limited. As one of the most important property of farmers, homestead has not been fully developed for a long time, and the current system has gradually failed to keep pace with the development of the times. As the most important link of land reform, the reform of rural homestead use right system has been explored by the state in the new round of rural land reform.

\section{Exploration on the Reform of Homestead Use Right System}

With the improvement of the overall level of economic development in rural areas, the farmers' demand for funds has become more and more intense, and they hope to obtain a large amount of funds for production and living. In addition, more and more rural villagers hope to move to cities and towns for employment, and this trend has also increased the financial needs of rural villagers. However, compared with cities and towns, farmers' ability to obtain funds is very limited, and they lack a large amount of liquidity. In the area surveyed by the author, I learned that the average annual income of farmers' families is very low, $89.7 \%$ of families earn their income by working outside or growing crops, and $70 \%$ to $80 \%$ of families have the will to move to cities and towns, but are limited by economic conditions. As the most valuable property of farmers, homestead is welfare - oriented. At present, this most valuable property has not been used well and its potential value has not been excavated fully. The solution to the contradiction between the large amount of idle land and the lack of liquidity funds is imminent. Because farmers have low ability to obtain funds and have limited access to them, if they want to obtain a large amount of funds, they can only rely on their most important asset-homestead. Farmers have limited access to sources of production and living funds. If they can allow the homestead to be mortgaged, they will certainly broaden their financing channels and stimulate their production and living consumption, thus driving the development of the whole rural economy. Therefore, in this realistic situation, the current homestead system needs to be reformed. 
The reform of the rural land system has taken place all over the world. Unlike the western private land system, China insists on making breakthroughs and seeking reform paths under the system framework of collective ownership of rural land. The Third Plenary Session of the Eighteenth Central Committee of the Party clearly demanded that farmers be granted more property rights. Through the pilot project to promote the mortgage, guarantee and transfer of farmers' housing property rights, it can be seen that the relevant regulations of the state on the transfer of homestead mortgage have been loosened, and policy support has also been provided to areas all over the country where the pilot reform of the mortgage of homestead use right has been carried out. From a practical point of view, many provinces and cities have begun to carry out the pilot reform of the right to use rural homestead. Allowing and releasing the right to use homestead and mortgage of rural house ownership is an inevitable requirement for flexible use of rural land resources and further development of rural economy, and is also an inevitable choice for deepening the reform of rural financial system, realizing farmers' land usufructuary right and obtaining funds for agricultural development. With the gradual improvement and maturity of various conditions, in January 2015, relevant state departments issued opinions on the reform of homestead, which marked the beginning of the pilot reform of the homestead use right system in China.

In order to ensure the smooth progress of reform according to law, the state allows pilot areas to temporarily suspend the implementation of relevant laws and regulations. On March 15, 2016, the People's Bank of China, China Banking Regulatory Commission, Ministry of Land and Resources and other relevant departments issued the Interim Measures for Farmers' Mortgage Loan of Housing Property Rights, with the pilot areas being 59 pilot counties (cities and districts) such as Jixian in Tianjin and Yicheng in Hubei, and the reform effect of the pilot areas was checked and accepted at the end of 2017. At this stage, the pilot broke through the following legal provisions:

Compared with Article 117 of the Property Law: " The usufructuary right holder shall have the right to possess, use and benefit from the real estate or motor cars owned by others according to law", Article 21 of the Decision of the Central Committee of the Communist Party of China on Several Major Issues Concerning Deepening Reform in an All - round Way of 2013 proposes to grant more property rights to farmers, allowing mortgage, guarantee and transfer of farmers' housing property rights through pilot projects .

Compared with Article 184 of the Property Law: " The following properties shall not be mortgaged: (2) Land use rights owned by collectives such as cultivated land, homestead, private plots and private hills, except those that can be mortgaged according to the law", Article 24 of the January 2015 " Opinions of the Central Committee of the Communist Party of China on Intensifying Reform and Innovation to Accelerate Agricultural Modernization" reads: " Do a good job in the pilot work of mortgage guarantee loans for contracted land and farmers' housing property rights, and encourage the development of" agriculture, countryside and farmers " financing guarantee business."

Compared with Article 37 of the Guarantee Law: " The following properties shall not be mortgaged: (2) Land use rights owned by collectives such as cultivated land, homestead, private plots and private hills, except as stipulated in Article 34 (5) and Article 36 (3) of this Law", Article 24 of the January 2015 " Opinions of the Central Committee of the Communist Party of China on Intensifying Reform and Innovation to Accelerate Agricultural Modernization" reads: " Do a good job in the pilot work of mortgage guarantee loans for contracted land and farmers' housing property rights, and encourage the development of" agriculture, countryside and farmers " financing guarantee business."

Compared with the first paragraph of Article 62 of the Land Administration Law: " Rural villagers can only own one homestead, and its homestead area shall not exceed the standards set by the provinces, autonomous regions and municipalities directly under the central government," Article 12 of the Interim Measures for Mortgage Loan of Farmers' Housing Property Rights of March 2016 stipulates: " As the borrower fails to perform due debts, sell or auction the mortgaged farmers' housing, the scope of the transferee shall, in principle, be limited within the limits set by relevant laws and regulations and the State Council ". 
The reform of the right to use homestead needs to break through some restrictions of existing laws and modify or suspend the implementation of relevant laws, but the legislation of homestead is not the only homestead law. Some rules spontaneously formed by people in the use of homestead are also an important part of the homestead system, and laws are the product of evolution rather than just the result of construction. The law of homestead includes both the law of legislation and the spontaneous rules in evolution. The law of legislation includes both the law of making legally binding laws and the policy law of actually playing a legal role. In practice, effective rules of behavior have been conceived or issued in various homestead use behaviors. Continuing to strengthen the control of homestead use rights will suppress farmers' enthusiasm and creativity in homestead use, and the result will inevitably harm farmers' interests and affect rural social development. Therefore, the effective homestead system is hidden in people's living experience of using homestead in real life and can only be discovered in practice.

\section{Conclusion}

Land use right system is a special usufructuary right system in our country, which mainly guarantees farmers' basic right to subsistence and has social welfare. However, with the improvement of rural social and economic level, the land use right in rural areas has transitioned from social security to property gradually. Under the background of the new round of rural land reform, the mortgage of land use right has become an inevitable requirement of the reform.

Since the beginning of the 21st century when the country launched the pilot reform of the right to use rural homestead, apart from the 59 pilot areas allocated by the state, some areas have tried to explore the reform of the right to use homestead as early as many years ago, which has aroused widespread concern and reflection from all walks of life. Most of the reform areas have achieved certain results and can provide certain reference and guidance for the reform in other areas. At present, although the reform of the right to use homestead faces great institutional obstacles at the legal level, the reform of the right to use homestead in all regions is carried out on the basis of local government documents, recognized by the relevant policy documents issued by the grass-roots government, and allows the pilot areas to suspend the implementation of relevant legal provisions during the pilot period. Generally, the reform of the right to use homestead in various regions has eased the financing difficulties of farmers to a certain extent, effectively increased farmers' property income and solved the pressure of some farmers' difficulties in starting businesses and employment.

\section{References}

[1]. Yuan Jinxiu. Research on the Legal Issues of Rural Homestead Use Right [M]. China Commerce Press, 2013.

[2]. Liu Daoyuan. Research on Legal Innovation of Collective Land Transfer [M]. Peking University Press, 2011.

[3]. Chen Xiao. Research on Rural Homestead Use and Mortgage - Based on Questionnaire Analysis of Farmers in Different Regions of Chongqing [J]. West forum, March2010.

[4]. Xu Hanming, Liu Chunwei. Research on Farmers' Willingness to Transfer Homestead Use Right and Its Influencing Factors - Based on a Questionnaire Analysis of 210 Households in Jiangxia District of Wuhan [J]. Journal of Northwest Agriculture and Forestry University (Social Science Edition), vol.12, June 2012.

[5]. Zhang Huilin. Institutional Obstacles and Solutions to Mortgage of Farmers' Housing Property Rights [J]. Gansu Social Sciences, February 2015.

[6]. Long Kaisheng. Realistic Logic and Path Selection of Reform of Homestead Use Right System [J]. Social Scientist, February2016. 
[7]. Zhong Sanyu. Dilemma and Innovation: Legal Thinking on Mortgage Financing of Homestead Use Right-From the Perspective of Property Right Attribute of Homestead Use Right [J]. Journal of Southwest University for Nationalities (Humanities and Social Sciences Edition), November 2014. 